\title{
Relevansi Doktrin Restorative Justice dalam Sistem Pemidanaan di Indonesia
}

\author{
The Relevance of the Doctrine on Restorative Justice in the Indonesian \\ Sentencing System
}

\section{Bambang Waluyo}

Jaksa Agung Muda Pembinaan, Kejaksaan Agung Republik Indonesia Jln.. Sultan Hasanuddin No.1, Kebayoran Baru, Jakarta Selatan, Indonesia Tel./Fax:+62-21-7221269 E-mail:nevarindu@yahoo.com

Submitted: Jun 12, 2015; Reviewed: Jul 2, 2015; Accepted: Jul 20, 2015

\begin{abstract}
Referring on the development of criminal law recently, it is inevitable to reform the criminal law through changes on the Indonesian Criminal Code (KUHP). Being derived from the foreign law (relic of the colonial era), the Criminal Code has been obsolete, injustice, outmoded and unrealistic irrelevant for the present reality. The type of research employed in this paper is normative research, reviewing the restorative justice principle from the perspective of the criminal law system, with the aim of constructing a restorative justice concept which is ideal to be applied in the Indonesian criminal law system. The concept of restorative justice is an approach of problem solving that emphasizes the recovery of victims and to restore the relationship between the perpetrator and the victim and to their respective communities. By using such approach, the parties are expected to reach a mutual agreement related to the settlement of disputes which expected to harmonize the relationship of the parties prior the occurrence of the crime. On the practical level, the principles on restorative justice for the settlement of criminal case may need to be implemented imminently as part of the criminal system in Indonesia.
\end{abstract}

Keywords: Law Reform; Legal Policy; Restorative Justice

\begin{abstract}
Abstrak: Menilik arah perkembangan hukum pidana dewasa ini, bermuara pada pembaharuan hukum pidana melalui perubahan KUHP sebagai sebuah keniscayaan. Selain karena KUHP berasal dari hukum asing (peninggalan zaman kolonial), materi muatan dalam KUHP pun telah usang dan tidak adil (obsolete and injustice) serta ketinggalan zaman dan tidak sesuai dengan kenyataan (outmoded and unreal). Jenis penelitian dalam tulisan ini adalah penelitian normatif, yang mengkaji relevansi doktrin restorative justice dari perspektif sistem hukum pidana Indonesia, sehingga dapat dikonstruksi sebuah konsep restorative justice yang ideal diterapkan dalam sistem pemidanaan di Indonesia. Konsep restorative justice merupakan pendekatan dalam penyelesaian masalah yang menekankan pada pemulihan kerugian korban dan pemulihan hubungan antara pelaku dengan korban serta komunitasnya masing-masing. Dengan menggunakan pendekatan ini, para pihak diharapkan dapat mencapai kesepakatan bersama terkait penyelesaian sengketa, sehingga dapat mengharmoniskan kembali hubungan para pihak seperti sebelum terjadinya tindak pidana. Pada tataran praksis, prinsip-prinsip restorative justice dalam penyelesaian perkara pidana perlu segera diterapkan sebagai bagian dari sistem pemidanaan di Indonesia.
\end{abstract}

Kata Kunci: Pembaharuan Hukum; Politik Hukum; Restorative Justice 


\section{PENDAHULUAN}

Sistem pemidanaan di Indonesia tidak dapat dilepaskan dari aturan tertulis yang bersumber dari hukum pidana peninggalan kolonial Belanda, yaitu Wetboek van Strafrecht voor Nederlandsch Indie (WVS Nl). WVS N1 ditetapkan sebagai hukum pidana materiil di Indonesia berdasarkan Undang-undang Nomor 1 Tahun 1946 tentang Peraturan Hukum dan secara resmi diberi nama Kitab UndangUndang Hukum Pidana (KUHP). Pemberlakuan WVS Nl sebagai KUHP Indonesia dilakukan dengan berapa perubahan dan penyesuaian, namun demikian sumber pokoknya tetap saja berasal dari KUHP warisan Pemerintahan Kolonial Belanda. Bahkan teks resmi KUHP yang sekarang berlaku di Indonesia, hingga saat ini masih dalam bahasa Belanda. ${ }^{1}$

Menilik latar sejarah berlakunya KUHP, maka pembaharuan hukum pidana (criminal law reform) melalui perubahan KUHP menjadi sebuah keniscayaan (necessary condition). Perlunya pembaharuan KUHP pun sejalan dengan hasil Kongres PBB tahun 1976 tentang pencegahan kejahatan dan perlakuan kepada pelaku kejahatan. Dalam kongres tersebut dinyatakan bahwa hukum pidana yang selama ini berlaku di berbagai negara pada umumnya berasal dari hukum asing dari zaman kolonial yang telah usang dan tidak adil (obsolete and injustice) serta ketinggalan zaman dan tidak sesuai dengan kenyataan (outmoded and unreal).

Hal ini dikarenakan hukum pidana tersebut tidak berakar pada nilai-nilai budaya

\footnotetext{
Soedarto. "Suatu Dilema dalam Sistem Pidana Indonesia," Pidato Pengukuhan Jabatan Guru Besar Hukum Pidana Universitas Diponegoro, Semarang: 21 Desember 1974.
}

dan bahkan ada yang tidak sesuai dengan aspirasi masyarakat serta tidak responsif terhadap kebutuhan sosial masa kini. Di sisi lain, di negara asalnya, hukum pidana tersebut sebenarnya juga telah mengalami beberapa kali perubahan yang disesuaikan dengan perkembangan zaman.

Salah satu materi muatan dalam KUHP yang menjadi sorotan berbagai pihak dan perlu segera dilakukan pembaharuan ialah sistem pemidanaan. Sistem pemidanaan dalam KUHP masih fokus pada penindakan terhadap pelaku kejahatan, belum memperhatikan pemulihan kerugian dan penderitaan) korban yang hilang akibat terjadinya kejahatan. Hal ini secara tegas tergambar dan jenis-jenis pemidanaan yang diatur dalam Pasal 10 KUHP, yaitu: 1) Pidana pokok, meliputi: pidana mati, pidana penjara, pidana kurungan, pidana denda, dan pidana tutupan; dan 2) Pidana tambahan, meliputi: pencabutan hak-hak tertentu, perampasan barang-barang tertentu, dan pengumuman putusan hakim.

Sistem pemidanaan yang tercantum dalam Pasal 10 KUHP tersebut pada hakikatnya masih menganut paradigma retributive, yaitu memberikan balasan yang setimpal atas kejahatan yang dilakukan oleh pelaku. Paradigma retributive dengan tujuan untuk memberikan efek jera (deterrent effect) agar pelaku tidak mengulangi lagi kejahatannya dan mencegah atau menangkal (prevency effect) masyarakat melakukan kejahatan. Penggunaan paradigma retributive, ternyata belum mampu memulihkan kerugian dan penderitaan yang dialami korban. Walaupun pelaku telah diputus bersalah dan mendapatkan hukuman, namun kondisi korban tidak 
dapat kembali seperti semula.

Dengan adanya kelemahan-kelemahan tersebut, muncullah gagasan tentang sistem pemidanaan yang berorientasi pada pemulihan kerugian dan penderitaan korban, atau yang dikenal dengan pendekatan restorative justice. Sebab korban merupakan pihak yang paling dirugikan akibat terjadinya sebuah kejahatan. Restorative justice dikemukakan untuk menolak sarana koersif dan menggantinya dengan sarana reparatif. Restorative justice mengakomodir kepentingan para pihak, termasuk korban karena korban dilibatkan dalam penentuan sanksi bagi pelaku.

Konsep restorative justice pada dasarnya bertujuan untuk mengembalikan konflik kepada pihak-pihak yang paling terkena pengaruh (korban, pelaku dan "komunitas mereka") serta memberikan keutamaan pada kepentingan-kepentingan mereka. Restorative justice mengupayakan untuk merestore keamanan korban, penghormatan pribadi, martabat, dan yang lebih penting adalah sense of control. Dengan menganut paradigma restorative justice, diharapkan kerugian dan penderitaan yang dialami korban dan keluarganya dapat dipulihkan dan beban rasa bersalah pelaku kejahatan dapat berukuran karena telah mendapatkan maaf dari korban atau keluarganya.

\section{METODE}

Jenis penelitian dalam tulisan ini adalah penelitian normatif, yang mengkaji relevansi doktrin restorative justice dari perspektif sistem hukum pidana Indonesia, sehingga dapat dikonstruksi konsep restorative justice yang ideal diterapkan dalam sistem pemidanaan di Indonesia. Data yang digunakan berupa data sekunder yang terdiri dari bahan-bahan hukum primer berupa peraturan perundangundangan, bahan hukum tersier berupa buku-buku referensi, pendapat ahli maupun hasil penelitian terdahulu, dan bahan hukum tersier berupa kamus-kamus bahasa, kamus ilmiah hukum dan black law dictionary.

Metode analisis dalam penulisan ini dimulai dengan mengabstraksi bahan-bahan hukum primer, bahan hukum sekunder dan bahan hukum tersier, sehingga diketahui hakikat konsep restorative justice dan relevansinya dalam sistem pemidanaan yang berlaku di Indonesia. Kemudian dilakukan sistematisasi dan terakhir dengan menggunakan metode penalaran silogisme deduktif. ${ }^{2}$

\section{ANALISIS DAN PEMBAHASAN \\ Definisi, Konsepsi, dan Prinsip-prinsip Restorative Justice}

Sebelum membahas lebih lanjut mengenai sistem pemidanaan yang berbasis pada keadilan restoratif (restorative justice), terlebih dulu akan dikemukakan definisi, konsepsi dan prinsip-prinsip restorative justice. Beberapa pakar hukum mengemukakan pengertian restorative justice dengan definisi yang berbeda, namun pada prinsipnya mengandung makna yang sama, yakni suatu konsep pemikiran terkait dengan sistem pemidanaan yang tidak hanya menitikberatkan pada kebutuhan dan penjatuhan hukuman terhadap pelaku, tetapi juga memperhatikan dan melibatkan korban dan komunitasnya (masyarakat) yang dirasa tersisihkan dengan me-

2 Peter Mahmud Marzuki. (2005). Penelitian Hukum, Jakarta: Kencana Prenada Media Group, hlm. 57 
kanisme kerja sistem peradilan pidana yang berlaku saat ini.

Howard Zehr' dalam bukunya "the little book of Restorative Justice" memberikan definisi tentang Restorative justice bahwa:

"Restorative justice" is a process to involve, to the extent possible, those who have a stake in a specific offense and to collectively identify and address harms, needs, and obligation in order to heal and put things as right as possible.

(Keadilan restoratif adalah proses untuk melibatkan dengan menggunakan segala kemungkinan, seluruh pihak terkait dan pelanggaran tertentu dan untuk mengidentifikasi serta menjelaskan ancaman, kebutuhan dan kewajiban dalam rangka menyembuhkan serta menematkan hal tersebut sedapat mungkin sesuai dengan tempatnya). ${ }^{4}$

Salah satu pengertian lain dirumuskan dalam Pasal 1 angka 6 Undang-Undang Nomor 1 Tahun 2012 tentang Sistem Peradilan Pidana Anak yang mendefinisikan keadilan

3 Howard Zehr. (2002). The Little Book of Restorative Justice. United State of America: Good Books Intercourse, hlm. 37

4 Pengertian lain dikemukakan oleh Menurut Tony Marshall: "Restorative justice" is a process whereby all the parties with a stake in a particular offence come together to resolve collectively how to deal wuth the aftermath of the offence and its implication for the future. Sedangkan menurut Doglas Y.R.N: "Restorative justice is criminal justice concept that views crime as a violation of people, not as a violation of the state, and creates on obligation to the victim and to the community to make things right. It focuses on the crimes harm rather than on the broken rule and emphasizes redress for the victim and community for the effects of the wrong doing over punishment imposed by the state. Restorative justice model may provide for appropriate dialogue, direct, between the victim and offender in the form of victim-offender mediation." Lihat Marshall, Tony F. (1999). Retorative Justice an Overview. London : Home Office, Information \& Publications Group, hlm. 5 restoratif sebagai:

Penyelesaian perkara tindak pidana dengan melibatkan pelaku, korban, keluarga pelaku/korban, dan pihak lain yang terkait untuk bersamasama mencari penyelesaian yang adil dengan menekankan pemulihan kembali pada keadaan semula, dan bukan pembalasan.

Beragamnya definisi restoratif justice yang dikemukakan oleh para pakar, menurut Miers, dikarenakan banyaknya variasi model dan bentuk yang berkembang dalam penerapannya. Hal ini memperbanyak terminologi yang digunakan untuk menggambarkan aliran keadilan restorasi, antara lain: communitarian justice (keadilan komunitarian); positive justice (keadilan positif); relasional justice (keadilan relasional); reparative justce (keadilan reparatif); dan community justice (keadilan masyarakat). ${ }^{5}$

Terminologi "Communitarian Justi$c e$ " berasal dari teori komunitarian yang berkembang di Eropa saat ini, seiring dengan mulai ditinggalkannya paham individualis dan munculnya kesadaran atas peran masyarakat dalam kehidupan seseorang. Teori komunitarian menempatkan keadilan restoratif pada posisi yang mengusung lembaga musyawarah sebagai upaya yang dapat dilakukan dalam mencari jalan terbaik atas suatu pemecahan masalah yang timbul akibat dilakukannya suatu tindak pidana. ${ }^{6}$

Secara konseptual, Agustinus Pohan ${ }^{7}$ mengelompokkan keadilan restoratif dalam

5 Eva Achyani Zulva dan Indriyanto Seno Adji. (2011). Pergeseran Paradigma Peidanaan, Bandung: Lubuk Agung, hlm. 66.

6 Ibid.

7 Agustinus Pohan. (tt). Diversi dan Restorative Justice dalam Undang-Undang Sistem Peradilan Pidana Anak, Paparan Power Point, Jakarta, hlm. 9-10. 
tiga kelompok, yaitu:

1. Encounter Conception. Konsepsi ini memandang keadilan restoratif sebagai suatu proses penyelesaian persoalan yang ditimbulkan dari suatu kriminalitas dengan cara mempertemukan korban, pelaku dan pemangku kepentingan lainnya dalam suatu forum informal yang demokratis untuk menemukan solusi yang positif. Bila cara ini dilakukan dengan benar, hal tersebut dipercaya akan merubah perilaku pelaku (rehabilitation), pencegahan (detererence), menyadarkan para pihak akan pentingnya norma yang telah dilanggar (reinforcement of norm), dan memungkinkan pemulihan korbannya melalui pemberian ganti rugi (restitusi).

2. Reparative Justice. Konsepsi ini memandang keadilan restoratif sebagai suatu konsepsi keadilan yang mengutamakan pemulihan terhadap kerugian (harm) dari pada sekedar memberikan penderitaan kepada pelakunya. Pendukung konsep ini percaya, ketika suatu kejahatan terjadi maka harus dilakukan tindakan yang benar khusunya untuk membangun kembali hubungan yang benar (re-establish just relationships). Hal ini berarti, konsep ini lebih menekankan tentang apa yang harus dilakukan untuk membangun kembali hubungan yang benar dari pada membalas perbuatan pelaku dengan memberikan hukuman.

\section{Transformative Conception. Konsepsi} ini memandang keadilan restoratif sebagai suatu way of life. Pendukung konsep ini memandang restorative justice bukan hanya soal perubahan pendekatan terhadap kejahatan tetapi harus lebih jauh lagi yaitu dalam rangka mencapai suatu masyarakat yang adil (achieving a just society), yang hanya bisa dicapai melalui transformasi untuk memahami keberadaan setiap orang sebagai bagian yang tidak terpisahkan dari masyarakat dan lingkungan. Pendekatan yang digunakan adalah 'kebutuhan' (need) dan bukan 'hak (right) atau 'ganjaran' (desert), di mana 'kebutuhan' untuk semua pihak (pelaku, korban, dan komunitas) adalah sama pentingnya.

Braithwite, ${ }^{8}$ ahli kriminologi Australia membedakan restorative justice, menjadi dua konsep yaitu: Pertama, fokus pada proses dan konsep (konsep), yaitu mempertemukan semua kepentingan yang terdampak oleh suatu kesalahan; dan Kedua, fokus pada nilai (values), yaitu keadilan restoratif sebagai nilai yang berkaitan dengan kesembuhan (pemulihan) dan ketidakadilan, serta menempatkan korban seperti sebelum terjadinya kejahatan, termasuk mereparasi hubungan antara korban dan pelaku. Hal ini berarti keadilan restoratif baik sebagai proses maupun sebagai nilai, erat kaitannya dengan rekonsiliasi antara korban dan pelaku.

Merujuk pada definisi dan konsepsi restorative justice sebagaimana telah dikemu-

8 Dikutip dari, Romli Atmasasmita, Cita Keadilan Restoratif Dalam Pembaharuan Hukum Pidana Indonesia, Makalah Kuliah Matrikulasi Mahasiswa program S2 Ilmu Hukum pada Fakultas Hukum Universitas Padjadajaran tanggal 1 September 2012. Makalah ini dengan beberapa revisi redaksional pernah dibacakan pada Seminar Nasional, "Peran Hakim dalam mengingatkan Profesionalisme Hakim Menuju Peradilan Yang Agung”, diselenggarakan IKAHI dalam rangka Ulang Tahun IKAHI ke 59 tanggal 25 April 2012, hlm. 12-13. 
kakan di atas, dapat diketahui bahwa penyelesaian perkara pidana dengan pendekatan keadilan restoratif pada hakekatnya akan melibatkan para pihak yang memiliki kepentingan dalam penyelesaian kasus tersebut.

Dalam hal ini, para pihak yang dimaksud adalah pelaku, korban dan komunitas masing-masing. Para pihak tersebut diharapkan dapat bermusyawarah untuk mencapai kesepakatan bersama dalam rangka menyelesaikan tindak pidana yang telah terjadi. Oleh karena proses restorative justice itu melibatkan para pihak yang berkepentingan, maka menurut "Handbook on Restorative Justice Program" yang publikasikan oleh PBB pada bulan November 2006, kegiatan restorative justice harus dilaksanakan dengan asumsi sebagai berikut: ${ }^{9}$

1. That the respon to crime should repair as much a possible the harm suffered by the victim (Tanggapan atas kejahatan yang harus diperbaiki sebaik mungkin serta ganti rugi atas penderitaan yang dialami korban). Asumsi ini menekankan bahwa korban harus diberi akses untuk dapat menjadi salah satu pihak yang menentukan penyelesaian akhir dari tindak pidana karena korban adalah pihak yang paling dirugikan dan yang paling menderita, sehingga korban dapat meminta upaya perbaikan atau penggantian kerugian yang dialaminya kepada pelaku.

2. That offenders should be brought to understand that their behavior is not acceptable and that it had some real

9 Eva Achyani Zulva dan Indriyanto Seno Adji, Op.Cit, hlm. 75-76. consequences for the victim and community (Pelaku harus dibawakan untuk memahami bahwa perilakunya tidak bisa diterima dan hal ini punya beberapa konsekuensi nyata untuk korban dan komunitas). Asumsi ini menekankan bahwa pelaku harus dibawa pada pemahaman dan kesadaran bahwa tindak pidana yang dilakukannya tidak dapat diterima masyarakat karena merugikan orang lain, baik itu korban secara langsung maupun komunitasnya. Dengan adanya kesadaran tersebut diharapkan pelaku bersedia untuk melakukan instrospeksi dan bersedia bertanggung jawab atas kerugian yang diakibatkan oleh perbuatan yang telah dilakukannya.

3. That offenders can and should accept responsibility for their action (Pelaku harus dapat menerima tanggung jawab yang timbul dari tingkah lakunya). Dengan adanya kesadaran atas kesalahannya, pelaku diharapkan memiliki kerelaan untuk bertanggung jawab. Tanpa adanya kesadaran atas kesalahan yang dilakukannya, mustahil pelaku bersedia secara sukarela untuk bertanggung jawab atas perbuatan yang dilakukannya.

4. That victim should have an opportunity to the express their needs and to participate in determining the best way for the offender to make reparation. (Korban harus memperoleh kesempatan untuk menyatakan keinginannya dan ikut serta menentukan langkah terbaik yang dapat dilakukan pelaku untuk memperbaiki kerusakan yang ditimbulkannya). 
Dengan adanya akses bagi korban untuk berpartisipasi dalam penyelesaian perkara, maka korban bukan hanya dapat berpartisipasi menyampaikan tun tutan ganti-rugi, tetapi juga punya kesempatan untuk berpartisipasi menumbuhkan kesadaran pelaku dan menentukan langkah terbaik untuk memperbaiki kerusakan yang ditimbulkan. Dengan demikian, akan muncul kaitan yang saling mempengaruhi antara korban dan pelaku dalam memilih penyelesaian terbaik sebagai upaya pemulihan hubungan sosial diantara keduanya.

5. That community has a responsibility to contribute to this process (Masyarakat diharapkan dapat ikut serta dalam proses). Proses penyelesaian perkara pidana dengan pendekatan keadilan restoratif bukan hanya milik pelaku dan korban. Masyarakat juga dianggap memiliki tanggung jawab baik dalam penyelenggaraan proses maupun pelaksanaan hasilnya, baik sebagai penyelenggara, pengamat maupun fasilitator serta bagian dari korban yang juga harus mendapatkan keuntungan atas hasil proses yang berjalan.

Terkait dengan berbagai asumsi di atas, Mackay mengemukakan prinsip-prinsip dasar restorative justice, baik yang terkait dengan pelaku dan korban; upaya perbaikan dan sanksi yang harus diterima pelaku; komunitas dan aparatur penegak hukum; lembaga yang terkait dengan lembaga peradilan; sistem peradilan pidana; maupun mediator.
1. Prinsip-prinsip restorative justice yang terkait dengan Para Pihak:

a) Voluntary participation and informed consent. Prinsip ini menekankan unsur kerelaan dari para pihak untuk mencari jalan keluar bagi penyelesaian perkara. Unsur kerelaan menjadi pembeda restorative justice dengan sistem peradilan pidana konvensional yang menekankan paksaan sebagai pangkal dari upaya penegakan hukum. Selain unsur kerelaan berpartisipasi, para pihak juga harus menjaga kerahasiaan bila ada hal-hal yang berkaitan dengan kesusilaan atau nama baik pihak yang terlibat perkara. Prinsip kerahasiaan ini menjadi sarana perlindungan bagi pelaku dan korban, bukan lawan dari prinsip transparansi dan akuntabilitas publik.

b) Non-discrimination, irrespective of the nature of the case. Prinsip ini melihat prinsip equality before the law yang berlaku dalam sistem peradilan pidana konvensional juga harus diterapkan dalam restorative justice. Kekhawatiran terjadinya diskriminasi dalam proses ini sering kali mengemuka, manakala perspektif patemalistik masyarakat mewarnai proses penanganan tindak pidana dalam masyarakat, utamanya masyarakat adat. Dengan berpegang pada prinsip ini, maka semua pihak memiliki posisi yang sama dalam menentukan penyelesaian perkara dengan pendekatan restorative justice. Namun demikian dalam kondisi tertentu, tetap bisa dilakukan pengecualian, tergantung 
sifat perkara dan kepentingan penyelesaiannya.

c) Accessibility to relevant helping agencies (including restorative practice agencies). Prinsip ini memungkinkan penggunaan berbagai upaya positif sepanjang tidak bertentangan dengan tujuan, asas-asas umum dalam hukum dan hak asasi manusia untuk mencari jalan terbaik dalam penyelesaian perkara. Bila para pihak merasa perlu melibatkan lembaga lain untuk menyelesaikan perkara, maka akses bagi lembaga tersebut untuk berpartisipasi harus dibuka seluas-luasnya. Lembaga dimaksud dapat berasal dari unsur pemerintah maupun non pemerintah seperti lembaga swadaya masyarakat.

d) Protection of vulnerable parties in process. Prinsip ini menekankan adanya perlindungan bagi pelaku dan korban yang tergolong dalam kelompok rentan seperti, perempuan, anak-anak, orang cacat, maupun mereka yang berusia lanjut, agar mereka dapat memiliki posisi yang sejajar dengan pihak lain. Terhadap perempuan dan anak-anak harus diberlakukan asas non-diskriminasi, sehingga mereka dapat menjalankan hak dan kewajibannya sebagai pihak yang berperkara. Untuk orang cacat dan usia lanjut, bantuan berapa alat khusus atau pendampingan khusus, sepatutnya diberikan kepada mereka agar dapat membantu mereka menjalankan hak dan kewajiban serta peranannya dalam proses yang ber- jalan.

e) Maintaining accessibility to conventional methods of dispute/case resolution (including court). Penyelesaian perkara dengan menggunakan pendekatan keadilan restoratif pada hakikatnya merupakan suatu pilihan yang ditawarkan, sehingga bukan berarti menghilangkan sistem peradilan pidana konvensional. Kehadiran sistem peradilan pidana tetap diperlukan manakalah pilihan ini tidak dapat menyelesaikan perkara. Bahkan pendekatan restorative justice juga dapat menjadi bingkai sistem peradilan pidana dalam rangka mencari bentuk terbaik penyelesaian perkara pidana di masyarakat, baik diselesaikan sendiri oleh masyarakat atau melibatkan sistem peradilan pidana.

f) Privilege should apply to information disclosed before that (subject to public interest qualification). Penyelesaian perkara pidana di luar pengadilan sering kali menemui kendala administrasi terkait hal-hal teknis yang seringkali bersifat rahasia dan pengungkapannya membutuhkan izin pengadilan. Dalam sistem peradilan pidana konvensional, hal-hal tersebut dikecualikan seperti rahasia jabatan. Dengan menggunakan keadilan restorative, sifat kerahasiaan tersebut mungkin menjadi relatif tergantung pada para pihak yang berkepentingan (utamanya pelaku dan korban). Sifat relatif tersebut berkaitan dengan pandangan para pihak, korban, pelaku atau masyarakat dalam me- 
mandang apakah hal-hal itu bersifat rahasia atau tidak. Ukuran yang jelas dan dapat menjadi patokan ialah hukum yang hidup dalam masyarakat.

g) Civil right and dignity of individual should be respected. Pendekatan restorative justice tetap memperhatikan nilai-nilai hak asasi manusia dalam masyarakat, bahkan hal tersebut menjadi prasyarat utama yang harus dipenuhi dalam penyelesaian perkara dengan pendekatan restorative justice. Hak asasi manusia disini ialah hak akan kebebasan pribadi dalam kaitannya dengan kebebasan mengungkapkan perasaan untuk memerhatikan kepentingan pribadi.

h) Personal safety to protected. Selain perlindungan akan kebebasan pribadi, perlindungan atas rasa aman juga menjadi prasyarat dalam penyelesaian perkara dengan menggunakan pendekatan restorative justice. Segala pernyataan akan menjadi percuma bila tidak ada jaminan perlindungan dan para pihak. Oleh karena itu jaminan keamanan ini menjadi bagian yang menentukan apakah proses tersebut berjalan dengan baik atau tidak.

2. Prinsip-prinsip restorative justice yang terkait dengan masyarakat dan lingkungan (komunitas):

a) Community safety should be promoted by measures to bring about crime prevention, harm reduction and social harmony. Keamanan masyarakat harus menjadi pertimbangan utama dalam penyelesaian perkara dengan menggunakan pendekatan keadi- lan restoratif. Sebab tujuan utama pendekatan ini pada dasarnya adalah untuk memulihkan hubungan sosial dalam masyarakat. Mustahil sistem ini dilaksanakan bila penggunaannya justru mengancam keselamatan masyarakat, menjadikan masyarakat tidak terlindungi, menimbulkan kerusakan atau menimbulkan disharmoni dalam masyarakat. Oleh karena itu, ada dua parameter utama suatu perkara tidak dapat diselesaikan dengan pendekatan ini ialah: 1) Bila penggunaan restorative justice justru menimbulkan pro dan kontra sehingga memicu munculnya sengketa baru; dan 2) Jenis pidana yang ditangani dianggap dapat mengancam keamanan masyarakat.

b) Social solidarity should be promoted by respect for cultural diversity. Keadilan restoratif sebenarnya sudah ada sejak dulu dalam masyarakat tradisional dan merupakan kearifan lokal yang sifatnya universal, sehingga nilai dasarnya, yaitu perdamaian hubungan sosial, merupakan nilai yang ada dalam masyarakat di dunia. Hanya saja setiap masyarakat memiliki nilai-nilai kearifan lokal yang beragam sehingga seringkali menimbulkan perbedaan interpretasi dalam tataran praktis, terutama bila para pihak yang terlibat berasal dari komunitas yang berbeda. Untuk itu dibutuhkan suatu kajian sosial yang mendalam sehubungan dengan masalah ini. Ikatan pemahaman bersama sebagai wujud solidaritas sosial di- 
anggap dapat menjadi perekat proses sehingga selayaknya hal ini dikedepankan.

c) Social solidarity should be promoted by upholding public morality and respect for the law. Solidaritas sosial harus diartikan sebagai adanya penyatuan pandangan dalam masyarakat terhadap kejahatan yang terjadi dan terhadap proses yang akan berjalan. Masyarakat diharapkan dapat menetapkan tujuan yang dapat menunjang proses penyelesaian perkara dengan pendekatan restorative justice.

3. Prinsip-prinsip restorative justice yang terkait dengan aparatur penegak hukum dan lembaga peradilan:

a) Consideration should be given to settlement of the case without prosecution except when the level of harm done, the risk of further harm, issues of public policy, disagreement about the fact or the appropriate outcome, requires open court action. Penyelesaian perkara di luar pengadilan dengan pendekatan restorative justice harus dijadikan pertimbangan penegak hukum untuk tidak melakukan penuntutan kecuali bila tingkat kesalahannya cukup berat, mengandung resiko kerusakan lebih lanjut, masalah yang menyangkut kepentingan umum, ketidaksepakatan tentang fakta atau hasil yang tepat, yang memerlukan tindakan pengadilan terbuka).

b) The exercise of discretion either individually or systematically should not compromise right under the law or lead discrimination. Pelaksanaan diskresi dari lembaga peradilan baik yang dilakukan secara individu maupun melalui sistem kelembagaan tidak boleh berkompromi baik berdasarkan atas hukum atau diskriminasi yang dibuat oleh pimpinan.

c) Restorative justice measures should not be subordinate to other criminal justice objectives such as diversion or rehabilitation. Pendekatan keadilan restoratif tidak harus tunduk dengan tujuan peradilan pidana lainnya seperti diversi atau rehabilitasi.

4. Prinsip-prinsip restorative justice yang terkait dengan sistem peradilan pidana:

a) Reintegration the parties should be the primary aim of court proceedings. Penyatuan kembali para pihak harus menjadi tujuan utama dari proses peradilan.

b) Repairing the harm should be the key objective in disposal of the case. Perbaikan kerusakan harus menjadi tujuan utama dalam pengesampingan perkara.

c) Restorative requirements should be proportionate the case. Persyaratan restoratif harus proporsional dan harus dilihat dalam kasus per kasus.

d) Where a restorative requirement is possible and proportionate, it should be imposed regardless of the wishes of the parties in criminal cases. Where a victim refuses to participate, a surrogate should be found. Persyaratan restoratif harus mungkin dan proporsional, serta harus dipaksakan terlepas dari keinginan para pihak dalam kasus pidana. Bila korban 
menolak untuk berpartisipasi, maka perwakilan harus ditemukan.

e) Genuine willingness on the part of the perpetrator to repair harm should be taken into account in disposal. Keinginan yang tulus dari pihak pelaku untuk memperbaiki kerusakan harus diperhitungkan dalam pengenyampingan perkara.

f) The content of mediation/conferences to be considered privilege subject to public interest qualifications. Hasil dari mediasi/musyawarah harus dijaga kerahasiaannya, terkait dengan kualifikasi kepentingan publik yang terkait.

5. Prinsip-prinsip restorative justice yang terkait dengan mediator:

a) Commitment to high-based practice, including a requirement that parties are advised of right and are encouraged to seek advice before commitment to mediate agreements. Komitmen untuk menghormati hak-hak individu harus menjadi dasar pelaksanaan proses, termasuk didalamnya hak-hak para pihak dan berusaha memberikan nasehat sebelum kesepakatan dibuat.

b) Impartiality of mediators. Ketidakberpihakan mediator.

c) Neutrality of mediators. Mediator harus netral.

d) Confidentiality as between parties and with regard to other agencies including "Chinese walls" with another part of the same agency having a district faction in respect of the case (this is to ensure that restorative practices are not undetermined by drives towards system integration). Mediator harus menjaga kerahasiaan antara para pihak dan menghormati lembaga lain yang juga menjadi mediator dalam kasus yang ditangani. Hal ini untuk memastikan bahwa penerapan keadilan restoratif tidak ditentukan ke arah sistem integrasi.

e) Facilitating the participation of $a$ weaker party with negotiation. Mediator harus memfasilitasi partisipasi pihak yang lebih lemah dengan negosiasi.

f) Upholding public moral standards of behavior in the mediation/conferencing process and in proposed settlement. Mediator harus menjunjung tinggi standar moral publik dalam mediasi/proses musyawarah dan di dalam mengajukan kesepakatan.

g) To have no other role in respect to the case. Mediator tidak boleh memiliki peran lainnya yang berkaitan dengan kasus tersebut.

h) Adherence to best practice guidelines within the restorative justice movement. Mematuhi pedoman yang baik dalam pelaksanaan gerakan keadilan restorative.

i) Commitment to an ethos of constructive conflict resolution within the workplace (this is to ensure internal integrity). Mediator harus memiliki komitmen yang mengikat ke satu etos pemecahan konflik yang bersifat membangun pada tempat kerja. Hal ini adalah untuk memastikan integritas internal. 
j) Commitment to improving practice through monitoring, audit, and participation in research. Mediator harus memiliki komitmen untuk meningkatkan praktek melalui pemantauan, audit, dan partisipasi dalam penelitian.

k) Commitment to improving practice through reflection upon practices and personal growth on the part mediator. Mediator harus memiliki komitmen untuk meningkatkan praktik yang tercermin pada saat pelaksanaan kegiatan dan kepribadiaan yang dibangun oleh mediator.

\section{Urgensi Penerapan Restorative Justice dalam Penyelesaian Perkara Pidana di Indonesia}

Pada subbahasan sebelumnya, telah dikemukakan bahwa sistem pemidanaan yang berlaku di Indonesia, khususnya yang tercantum dalam KUHP dan KUHAP masih menggunakan paradigma retributif. Penegakan hukum yang hanya berorientsi pada keadilan retributif, yang lebih menekankan pada penjatuhan hukuman terhadap pelaku seringkali tidak dapat menyelesaikan permasalahan sosial yang timbul sebagai akibat kejahatan pelaku. Sebab walaupun pelaku sudah dijatuhi hukuman namun pihak korban sering kali masih belum bisa memaafkan pelaku, sehingga benih-benih konflik antar keluarga pelaku dan keluarga korban setiap saat bisa kembali muncul dan membawa korban. Namun bila proses penegakan hukum juga memperhatikan kepentingan korban, diharapkan hal-hal seperti ini tidak terjadi dan diantara pihak korban dan pelaku dapat hidup berdampingan secara damai seperti sebelum terjadinya kejahatan.

Tuntutan penegakan hukum yang berorientasi pada keadilan restoratif, sangat dipengaruhi oleh terdegradasinya praktek penegakan hukum yang sesuai nilai-nilai kebenaran dan keadilan, serta penghormatan terhadap hak-hak azasi manusia, yang terjadi selama ini, sebagaimana terlihat dalam kasusu pencurian semangka, tiga butir bija kakao, penebagan pohon bamboo yang merintangi jalan dan sebagainya. Kondisi seperti ini tentu saja sangat jauh dari nilai-nilai yang terkandung dalam substansi supremasi hukum. Sebab tujuan utama dari supremasi hukum itu sendiri pada hakekatnya adalah untuk melindungi hak-hak warga negara baik dari kesewenang-wenangan penguasa maupun kesewenang-wenangan warga negara lainnya. Untuk itulah maka penerapan paradigma restorative justice merupakan sesuatu yang sangat berarti (signifikan) dan sangat periu segera diterapkan dalam sistem pemidanaan di Indonesia.

Urgensi penerapan pendekatan restorative justice dalam sistem pemidanaan di Indonesia juga sejalan dengan pendapat Marc Levin yang menyatakan bahwa pendekatan yang dulu dinyatakan usang, kuno dan tradisional kini justru dinyatakan sebagai pendekatan yang progresif. $^{10}$ Apa yang dikemukakan oleh Marc Levin tersebut sebenarnya tidaklah salah, sebab pendekatan restorative justice sudah ada dalam sistem pemidanaan menurut hukum adat yang berlaku di berbagai negara, termasuk di Indonesia. Selain itu, dalam konteks Indonesia,

10 Marc Levin. (2005). Restorative justice in Texas: Past, Present and Future, Texas: Texas Public Policy Foundation, hlm. 5-7. 
penerapan restorative justice juga dapat mengurangi permasalahan kepadatan lembaga pemasyarakatan yang di Indonesia menjadi persoalan yang cukup serius.

Sangat dirasakan akibat dari pendekatan legalistik penuntutan yang dilakukan oleh Kejaksaan maka banyak pelaku tindak pidana yang dijatuhi hukuman pidana. Akhir dari penjatuhan pidana adalah terpidana menjadi narapidana di Lembaga Pemasyarakatan. Dampaknya Rumah Tahanan Negara (RUTAN) dan Lembaga Pemasyarakatan (LAPAS) menjadi penuh, yang melahirkan problem kompleks sehingga tujuan pemasyarakatan dan kemanfaatannya tidak dapat dirasakan masyarakat.

Dalam hal ini Romli Atmasasmita ${ }^{11}$ antara lain berpendapat, manfaat satu-satunya menempatkan orang di dalam penjara selama waktu yang cukup lama yang pasti pelaku kejahatan mengalami isolasi fisik dan mental dan bahkan mendekati "kematian perdata" seumur hidupnya; lebih buruk lagi beaijung pada kematian. Negara tidak mengambil manfaat, bahkan pada kenyataannya menanggung beban ekonomi yang tinggi (high cost economy)

Dengan demikian, penerapan pendekatan restorative justice dalam sistem pemidanaan Indonesia sangat diperlukan dan diyakini dapat memberikan manfaat yang sangat berarti, baik itu bagi pelaku, korban dan komunitasnya masing-masing maupun bagi Negara. Bagi pelaku, korban dan masyarakatnya, manfaat tersebut sudah panjang lebar dikemukakan pada pembahasan terdahulu. Sementara bagi Negara, hal ini diya-

11 Romli Atmasasmita, "Efektifitas Hukuman Badan (Penjara)", Harian Seputar Indonesia, 14 Februari 2013. kini dapat membawa manfaat antara lain:

a. Tercapainya tujuan penegakan hukum yaitu keadilan, kepastian hukum, dan kemanfaatan bagi masyarakat.

b. Tercapainya cita-cita peradilan yang cepat, sederhana, murah efektif, dan efisien.

c. Penguatan institusi kejaksaan, aparaturnya, peran sertanya dan peningkatan kepercayaan publik.

d. Penghematan keuangan negara.

e. Over kapasitas RUTAN dan LAPAS dapat dikurangi atau dihindari.

f. Pengurangan penumpukan perkara di kejaksaan dan pengadilan.

g. Pemasukan kepada pendapatan keuangan negara, asset recovery, penyelamatan keuangan negara, dan sebagainya.

\section{Kebijakan Legislasi Terkait Penerapan Restorative Justice dalam Sistem Pemida- naan di Indonesia}

Kebijakan legislasi terkait dengan penerapan konsep restorative justice sebenarnya telah ada dasarnya dalam sistem pemidanaan di Indonesia. Hal ini dapat dilihat dalam Pasal 5 ayat (1) Undang-Undang Nomor 48 Tahun 2009 tentang Kekuasaan Kehakiman, yang menyatakan, "hakim dan hakim konstitusi wajib menggali, mengikuti, dan memahami nilai-nilai hukum dan rasa keadilan yang hidup dalam masyarakat'; dan Pasal 8 ayat (4) Undang-Undang Nomor 16 Tahun 2004 tentang kejaksaan yang mengatur, "dalam melaksanakan tugas dan wewenangnya, jaksa senantiasa bertindak berdasarkan hukum dengan mengindahkan norma-norma keagamaan, kesopanan, kesusilaan, serta 
wajib menggali dan menjunjung tinggi nilainilai kemanusiaan yang hidup dalam masyarakat, serta senantiasa menjaga kehormatan dan martabat profesinya".

Ketentuan Pasal 5 ayat (1) UU No. 48 Tahun 2009 merupakan landasan yuridis bagi adanya penemuan hukum oleh hakim. Sedangkan Pasal 8 ayat (4) UU No. 16 Tahun 2004 merupakan landasan yuridis bagi adanya penemuan hukum oleh jaksa. Penemuan hukum oleh hakim tentu tidak menjadi masalah, karena hakim bukan lagi bertindak sebagai corong undang-undang tetapi corong keadilan.

Namun bagi jaksa, hal tersebut tidak bisa diterapkan mentah-mentah karena kejaksaan dianggap sebagai alat negara penegak hukum yang bersama-sama kepolisian bertugas menegakkan hukum dan peraturan perundang-undangan, karena itulah dalam bahasa Belanda ada istilah de sterke arm van de wet (tangan kuat undang-undang). Tugas jaksa ialah melaksanakan undangundang, bukan melanggar undang-undang. Oleh karena itu, bila kejaksaan dituntut untuk dapat menerobos peraturan perundangundangan, maka kejaksaan harus diberi landasan yang kuat agar dapat melakukan hal tersebut. Tanpa adanya landasan yuridis yang kuat, pelanggaran atas peraturan perundang-undangan yang berlaku justru akan menimbulkan polemik baru dalam upaya penegakan hukum.

Di berbagai negara yang menganut sistem Eropa Kontinental penemuan hukum oleh jaksa dapat dilakukan dengan berpijak pada asas oportunitas yang menjadi kewenangan semua jaksa. Di Belanda misalnya, semua jaksa (officier van justitie) bo- leh men-seponer perkara berdasarkan Pasal 167 Strafvordehng (KUHAP Belanda). Namun di Indonesia, untuk mencegah hal-hal negatif, misalnya komersialisasi jabatan dan kolusi, asas oportunitas tersebut, sejak tahun 1961 hanya diberikan kepada Jaksa Agung Rl. Oleh karena itu, bila jaksa ingin mengenyampingkan perkara yang bukti-bukti dan saksinya cukup, ia harus memohon agar perkara tersebut dikesampingkan oleh Jaksa Agung. ${ }^{12}$

Selain itu, Undang-Undang Kejaksaan RI juga mengartikan secara sempit frase "demi kepentingan umum" sebagai "kepentingan negara atau masyarakat. Padahal di negara lain yang menganut asas oportunitas "demi kepentingan umum* diartikan secara luas, meliputi: ${ }^{13}$

a. Pemidanaan dipandang kurang efektif, misalnya (kalau di indonesia) pencurian sandal jepit bekas;

b. Tidak adil;

c. Anak di bawah umur;

d. Usia lanjut; dan

e. Ada sanksi yang efektif seperti ganti kerugian; sanksi administratif, perdata dan lain-lain.

Ketentuan tersebut dimasukkan dalam KUHAP Belanda dan dijadikan jaksa untuk mengesampingkan perkara pidana yang alat buktinya telah cukup. Dengan dasar tersebut, menurut keterangan Ahli Kejaksaan Belanda Prof. Mr. Dr. Strijds, pada tanggal 15 Juni 2010 di kantor Kejaksaan Den Hagg, kepada delegasi Kejaksaan Agung RI, 60\%

12 Ibid, hlm 73.

13 Andi Hamzah. "Justice Collaborator atau Saksi Mahkota," Jurnal Bhina Adhyaksa, 6(1) Juli 2012, Jakarta: Pusat Litbang Kejaksaan Agung, hlm. 13-14 
perkara pidana di Belanda diselesaikan di luar pengadilan oleh jaksa (transaction of judiciary). ${ }^{14}$ Oleh karena itu, bila ketentuan seperti yang berlaku di Belanda tersebut juga berlaku di Indonesia, maka ke depan diharapkan sudah tidak ada lagi kasuskasus seperti: pencurian tiga biji buah kakao oleh nenek Minah; pencurian Semangka yang dilakukan oleh Basar Suyanto dan Kholil; pemotongan pohon bambu karena merintangi jalan yang dilakukan oleh Budi Hermawan dan Munir; pencurian $5 \mathrm{Kg}$ buah randu yang dilakukan oleh Manisih, SRI, Juwono dan Rustono di Batang; pencurian kakek Klijo Sumarto, dan lain sebagainya. ${ }^{15}$ Sebab penuntutan terhadap kasus-kasus seperti itu justru dianggap melukai rasa keadilan masyarakat. Namun di sisi lain, jaksa tidak memiliki dasar kewenangan untuk mengesampingkan penuntutannya.

Upaya tersebut sebenarnya telah digagas oleh para penyusun RUU KUHAP, dengan memasukkan ketentuan Pasal 42 ayat (2) dan ayat (3) RUU KUHAP Tahun 2010 dan tahun 2013 yang menyatakan:

(2) Penuntut Umum juga berwenang demi kepentingan umum dan/atau dengan alasan tertentu menghentikan penuntutan baik dengan syarat maupun tanpa syarat,

(3) Kewenangan penuntut umum sebagaimana dimaksud pada ayat (2) dapat dilaksanakan jika:

a. Tindak pidana yang dilakukan bersifat ringan;

b. Tindak pidana yang dilakukan diancam dengan pidana penjara paling lama 4

14 Ibid.

15 Gde Made Swardhana, Progresifitas Kejaksaan di Indonesia, makalah disampaikan dalam seminar Pembaharuan Undang-undang Kejaksaan Republik Indonesia yang diselenggarakan oleh Kejaksaan Agung Rl dan Kejaksaan Tinggi Bali pada tanggal 27 Juli 2001 di Hotel Sindhu Beach Sanur Denpasar, hlm. 1 (empat) tahun.

c. Tindak pidana yang dilakukan hanya diancam dengan pidana denda;

d. Umur tersangka pada waktu melakukan tindak pidana di atas 70 (tujuh puluh) tahun, dan/atau

e. Kerugian sudah diganti.

Selain itu, beberapa peraturan perundang-undangan yang saat ini berlaku di Indonesia sebenarnya juga telah memuat nilai-nilai restorative justice, walaupun hal itu tidak dilakukan secara utuh. Beberapa ketentuan tersebut antara lain:

a. Pasal 98 ayat (1) KUHAP yang mengatur tentang penggabungan perkara pidana dengan tuntutan ganti rugi bila tindak pidana yang didakwakan menimbulkan kerugian bagi orang lain;

b. Pasal 63 huruf Undang-Undang Nomor 8 Tahun 1999 tentang Perlindungan Konsumen. Dalam ketentuan tersebut pidana pembayaran ganti rugi dikelompokan sebagai pidana tambahan bersama dengan pidana tambahan lainnya, yaitu: perampasan barang tertentu; pengumuman keputusan hakim; perintah penghentian kegiatan tertentu yang menyebabkan timbulnya kerugian konsumen; kewajiban penarikan barang dari peredaran; dan pencabutan izin usaha.

c. Pasal 53 Undang-undang Nomor 26 Tahun 2000 tentang Pengadilan Hak Asasi Manusia. Berdasarkan ketentuan tersebut setiap korban pelanggaran hak asasi manusia yang berat dan atau ahli warisnya dapat memperoleh kompensasi, restitusi, dan rehabilitasi. Restitusi harus dicantumkan dalam amar putusan Pengadilan HAM dan tata caranya 
diatur lebih lanjut dengan Peraturan Pemerintah.

d. Pasal 48 s/d Pasal 50 Undang-undang Nomor 21 Tahun 2007 tentang Pemberantasan Tindak Pidana Perdagangan Orang. Di dalam berbagai ketentuan tersebut diatur tentang pembayaran ganti rugi dan kompensasi bagi korban tindak perdagangan orang.

Namun demikian, berbagi aturan tersebut nampaknya belum begitu efektif dalam memberikan perlindungan kepada korban, karena mekanisme penuntutan ganti rugi yang belum berjalan dengan efektif. Selain itu, dengan adanya pembayaran ganti rugi, hal tersebut tidak membebaskan pelaku dari hukuman sehingga hal ini dapat mengurangi kerelaan pelaku untuk memberikan ganti kerugian.

\section{PENUTUP}

Konsep restorative justice merupakan pendekataan dalam penyelesaian masalah yang menekankan pada pemulihan kerugian korban dan pemulihan hubungan antara pelaku dengan korban serta komunitasnya masing-masing. Dengan menggunakan pendekatan ini, para pihak diharapkan dapat mencapai kesepakatan bersama terkait penyelesaian sengketa, sehingga dapat mengharmoniskan kembali hubungan para pihak seperti sebelum terjadinya tindak pidana. Pada tataran praksis, prinsip-prinsip restorative justice dalam penyelesaian perkara pidana perlu segera diterapkan sebagai bagian dari sistem pemidanaan di Indonesia.

Penerapan paradigma restorative justice dalam penyelesaian perkara pidana di Indonesia memiliki landasan yang cukup kuat, baik dari sisi historis, sosiologis, filosofis, maupun dari sisi perlindungan hak asasi manusia, nilai-nilai agama yang dianut masyarakat Indonesia, dan nilai-nilai budaya masyarakat.

Penerapan restorative justice diyakini dapat memberikan manfaat antara lain: menimbulkan keharmonisan dalam kehidupan bermasyarakat; memulihkan kerugian dan penderitaan korban; terwujudnya sistem peradilan yang cepat, sederhana, dan biaya murah; mengurangi permasalahan over kapasitas yang terjadi di Rutan dan LP; menghemat anggaran negara; dan mengurangi penumpukan perkara di pengadilan dan di kejaksaan. Dengan demikian, pelaksanaan penyelesaian perkara pi-dana dengan menggunakan paradigma restorative justice dengan konsisten dan sungguh-sungguh, diharapkan dapat me wujudkan tujuan penegakan hukum yaitu keadilan, kepastian hukum, dan kemanfaatan bagi masyarakat yang pada akhirnya dapat menunjang terwujudnya suatu masyarakat yang tertib, tentram, damai, adil, dan sejahtera (tata tentrem kerta raharja).

\section{BIBLIOGRAFI}

Andi Hamzah. "Justice Collaborator atau Saksi Mahkota," Jurnal Bhina Adhyaksa, 6(1): Juli 2012, Jakarta: Pusat Litbang Kejaksaan Agung.

Eva Achyani Zulva dan Indriyanto Seno Adji. (2011). Pergeseran Paradigma Peidanaan, Bandung: Lubuk Agung.

Gde Made Swardhana, Progresifitas Kejaksaan di Indonesia, Makalah disampaikan dalam seminar Pembaharuan Undang-Undang Kejaksaan Republik Indonesia yang diselenggarakan oleh 
Kejaksaan Agung Rl dan Kejaksaan Tinggi Bali, 27 Juli 2001 di Hotel Sindhu Beach Sanur Denpasar.

Howard Zehr. (2002). The Little Book of Restorative Justice. United State of America: Good Books Intercourse.

Marc Levin. (2005). Restorative justice in Texas: Past, Present and Future, Texas: Texas Public Policy Foundation.

Marshall, Tony F. (1999). Retorative Justice an Overview. London : Home Office, Information \& Publications Group.

Peter Mahmud Marzuki. (2005). Penelitian Hukum, Jakarta: Kencana Prenada Media Group.
Harian Seputar Indonesia. "Efektifitas Hukuman Badan (Penjara)", Edisi 14 Februari 2013.

Romli Atmasasmita. "Cita Keadilan Restoratif Dalam Pembaharuan Hukum Pi-dana Indonesia”. (Makalah). Kuliah Matrikulasi Program Magister Ilmu Hukum Program Pascasarjana Universitas Padjadajaran.

Soedarto. "Suatu Dilema dalam Sistem Pidana Indonesia," Disampaikan pada Pidato Pengukuhan Jabatan Guru Besar Hukum Pidana Universitas Diponegoro, Semarang, 21 Desember 1974. 